WHO'S BLACK AND WHY? 


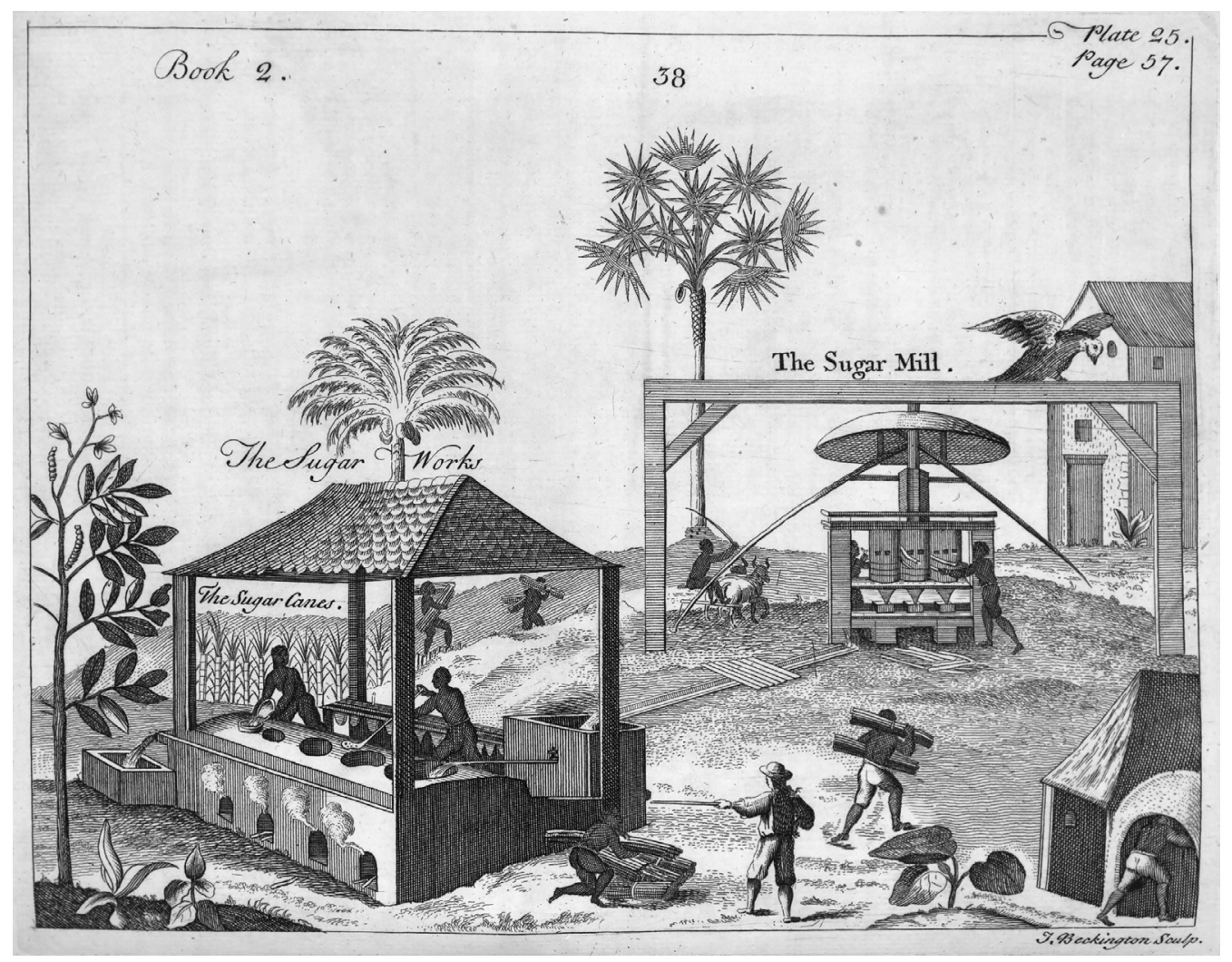




\section{Who's Black and Why?}

A Hidden Chapter from the

Eighteenth-Century Invention of Race

EDITED BY

Henry Louis Gates, Jr.,

and Andrew S. Curran

THE BELKNAP PRESS OF

HARVARD UNIVERSITY PRESS

Cambridge, Massachusetts

London, England 2022 
Copyright $(92022$ by Henry Louis Gates, Jr., and Andrew S. Curran All rights reserved

Printed in the United States of America

First printing

Cover design by Ben Blount

9780674276123 (EPUB)

9780674276130 (PDF)

The Library of Congress has cataloged the printed edition as follows:

Names: Gates, Henry Louis, Jr., editor. | Curran, Andrew S., editor.

Title: Who's black and why? : a hidden chapter from the eighteenth-century invention of race / edited by Henry Louis Gates, Jr. and Andrew S. Curran.

Description: Cambridge, Massachusetts : The Belknap Press of Harvard University Press, 2022. | Includes bibliographical references and index.

Identifiers: LCCN 2021036013 | ISBN 9780674244269 (cloth)

Subjects: LCSH: Académie royale des sciences (France) | Racism in anthropologyEurope-History-18th century. | Scientific racism-Europe-History18th century. | Black race-Color-Europe-History-18th century. |

Black race-Color-Europe-Public opinion-History-18th century. |

Europeans-Attitudes-History-18th century. | Racism-France-

Bordeaux (Nouvelle-Aquitaine)

Classification: LCC GN27.C38 2022 | DDC 305.8009409/033-dc23

LC record available at https://lccn.loc.gov/2021036013 
For Karen C. C. Dalton and Sheldon L. Cheek

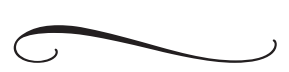


